\title{
Environmental Aspects of Concrete and Use of Waste Glass
}

\author{
${ }^{\text {"1 }}$ Snehal Abhyankar, ${ }^{2}$ Meenakshi Chouragade \\ ${ }^{1}$ Department of Civil Engineering, V.N.I.T, Nagpur, India \\ ${ }^{2}$ Department of Civil Engineering, K.I.T.S, Ramtek, India \\ Email:snehal.abhyankar@gmail.com, meenakshi.uchibagale@gmail.com
}

Received: 06th November 2019, Accepted: 10th February 2020, Published: 29th February 2020

\begin{abstract}
In this world Cement Concrete Industry plays major role for using natural resources to the tune of 12.6 billion tons. As per survey report overall 26 billion tons of aggregate or construction materials waste is generated by concrete industry. Sand aggregates and naturally available stones are frequently used in infrastructure. The replacement of natural aggregates by artificial aggregates is demand of enviornmental conditions. The use of artificial or stone crushed aggregates impacts the quality and durability of concrete. As crushed stone aggregates are prepared their production has negative impact on nature. They also increase the water content of concrete. These quarries acting as threat to environment causing many problems.Solution for this problem is to be found. The problem may be solved by replacing fine aggregate by waste glass in proper proportion. So it will lead to less consumption of sand. It may also help in reducing the hazardous effects of river dredging. So our construction materials manufacturing industry may become sustainable. Our aim is to achieve sustainable concrete industry waste materials that can be used in place of natural available resources like waste plastic, waste glass, waste rubber etc. There is much scope for reuse of waste glass in constrnction industry in India. This aspect may decrease the issues like solid waste management and the greening of the environment. In Concrete pavements, pavers are subjected to varying traffic condition, so microcracks are formed. Due to this both compressive and flexural strength decreases. In the current work the concrete mixes were prepared by replacing $10 \%, 15 \%, 20 \%, 25 \%$ and $30 \%$ of fine aggregate with fine glass aggregate. The assessment of workability and both compressive and flexural strength characterization was done for glass modified Concrete mixes. The workability decreased up to $16.6 \%$ with $20 \%$ fine glass aggregate, but with $25 \%$ and $30 \%$ of fine glass aggregate the workability showed an increasing trend. Further the compressive strength and flexural strength of fine glass aggregate modified mixes showed an increasing trend. The present study will be useful in providing an alternative for effective re-use of fine waste glass in concrete mixes. It may lead to reduce landfill waste. Reuse of waste will generate renewable and non-renewable resources. It will also reduce quarrying of raw materials.
\end{abstract}

\section{Keywords}

Concrete, Fine Glass Aggregate, Workability, Compressive Strength, Flexural Strength, Reuse, Sustainable

\section{Introduction}

Municipal solid waste main component is glass waste. It may be recyclable or non recyclable. Bottles, light bulbs, TV tubes, broken glassware are main components of solid waste. Products such as electric bulbs, broken glass, glass doors, and window panels are non recyclable waste. Simply dumping of these glass waste create huge land filling which attracts insects and flies and lead to viral infections. Solution is to be found out for such dumping. Hence the current research was undertaken on the use of waste glass as construction material to avoid waste disposal problems and to create clean environment.

The review of past studies showed that glass can be reused in crushed form or glass to provide proper interconnection in cement paste and aggregates. [5] Research shows that increase in compressive strength if waste glass materials used in concrete construction. Glass contains silica which enhances structural properties by reacting with cement paste. In different cement concrete mixes sand is replaced partially by waste glass. Further, the study focuses on the assessment of compressive strength and flexural strength characteristics of Concrete mixes using waste glass fine aggregate as partial replacement for fine aggregates. [7] NDT testing may be required. In this experimental programme, properties of all the ingredients used, Mix design, mixing process of both FWGAC and GFRC, procedures of tests are done.

Water absorption testing carried out to know effect of waste glass use. [1] Use of waste glass in concrete can prove to be economical as it is non useful waste and free of cost. As we all are aware of dumping and disposal of waste glass creates piles of garbage. Its use in cement concrete mixes may provide new solution to environmental problems. As natural sources of sand depleting at faster pace, crushed sand or manufactured sand or replacement by waste crushed glass is good option. [12]

As environmental aspects arise use of waste glass in concrete is encouraging. [6] Glass has natural hardness so it will help to increase strength of concrete. It may lead to high strength and high performance. Other uses like glass fibres, glass panels, replacing sand with crushed waste glass is further future scope. [3] 


\section{Methodology \\ Preparation of FWGAC and GFRC Mixes: \\ Mixing of FWGAC Ingredients}

For the mixing of ingredients used in preparing FWGAC mixes, mechanical drum mixer confirming the requirement of IS 1791 and IS 12119 is used. First the mixer was loaded with all dry materials such as cement, coarse aggregates, fine aggregate (natural sand) and glass aggregates, mixer was started and let for 1 minutes ,then $70 \%$ water was added and let for 1.5 minutes , mixer was stopped to check the consistency and the remaining water was added and were mixed for 1 more minute. The entire mixing time taken was about 3.5 minutes. Figure 1 presents materials used in FWGAC.

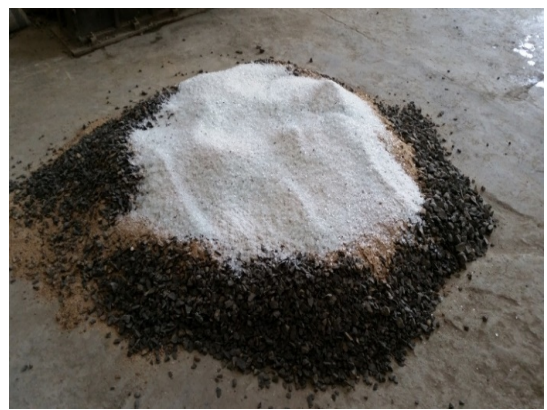

Figure 1: Materials Used in Preparation of FWGAC

\section{Mixing of GFRC Ingredients}

For the mixing of GFRC mixes, mechanical drum mixer confirming the requirement of IS 1791 and IS 12119 is used. First the glass fibre was manually added into cementitious materials for the purpose of avoiding balling effect of fibres, then it was mixed with fine aggregates then coarse aggregates and then mixer was loaded with all these dry materials. [10]

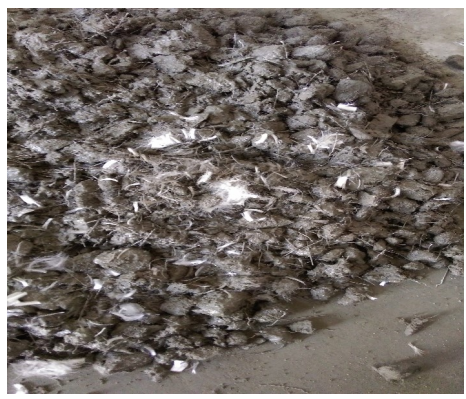

Figure 2: Addition of Glass Fibres with Cementitious Materials

\section{Effect of FWGA on Workability Characteristics of Concrete Mix}

In the present study, test is adopted as the measure of FWGAC is slump. The influence of fine waste glass aggregates with respect to different percentage dosage on workability behaviour of FWGAC mixes was assessed. The test was conducted as accordance with IS-1199-1995. As addition of waste glass started slump goes on decreasing. Concrete mix slump obtained was as $30 \mathrm{~mm}$. On 12\% and 17\% replacement, a gradual decrease of slump value is seen, while the optimum value for slump was found corresponding to $20 \%$ fine aggregates replacement in conventional Concrete mix, in which the slump value reduced to $20 \%$. The slump value increased with further replacement, such that with $25 \%$ replacement it was $8 \%$ more than mix with optimum content of FWGA and with $30 \%$ replacement slump was $25 \%$ higher than the mix with optimum content of FWGA but this value of slump was equal to that of conventional Concrete mix.

\section{Effect of FWGA on Compressive Strength Characteristics of Concrete Mix}

Corresponding to $20 \%$ FWGA replacement comparative analysis of FWGAC mixes were done. The trend shows that if fine waste glass aggregates were used it enhances compressive strength by $18 \%$ than conventional mixes. The comparison was done for 7 days and 28 days testing.

\section{FWGA Behavior for Flexural Strength Check}

FWGAC mixes are shown in Figure $1 \&$ Figure 2. Different results obtained were studied and discussed. Post analysis graphs were plotted. Common trend obtained was rise in compressive strength in concrete mixes. Now the results for flexural strength under study and focused. As we observed that flexural strength trend also 
shows positive results. [12] Every research demands optimization point to replacement. [11] This study leads to optimized point or percentage of $25 \%$ so to get desired results.

\section{UPV Tests}

It is observed that a small amount of waste glass replacement (5\%) resulted in a higher UPV, which may lead to effective use of glass. This may be attributed to the lower specific gravity of glass particles in comparison to that of sand. High content of irregular waste glass may also result in bridge of irregular particles or inconsistent structures (Abdallah and Fan, 2014).As sand has less specific gravity as compared to glass. UPV results give guidelines for qualitative analysis of strength.

Data were collected from FWGA and GFRC Mixes Experimental Lab work. Similarly Graphs were plotted for Compressive strength and Flexural Strength. For FWGAC containing 10\%, 15\%, 20\%, 25\% and 30\% glass aggregate as partial replacement for natural sand and for GFRC containing 1\%,2\%, and 3\% AR glass fibre by weight of cement is done.

\section{Result \& Discussion}

The flexural strength and compressive strength characteristics were studied. As waste dumped glass can be effectively utilized to enhance strength characteristics of concrete mixes. Both FWGAC and GFRC show very good results by destructive as well as non destructive testing. Workability parameter has to be controlled and monitored.

\section{Conclusion}

The future study will demand use of waste plastic, waste paper, waste agro products, waste food product to be utilized effectively to enhance strength and other capacities of different cement concrete mixes.

\section{References}

1. "Concrete Pavements." ACI Materials Journal 100(2):150-155.

2. ACI Board Advisory Committee on Sustainable Development 2004. "White Paper."

3. Coppola, L., Cerulli, T., \& Salvioni, D. 2004. "Sustainable Development and Durability of Self-Compacting Concretes."

4. Eighth CANMET/ACI International Conference on Fly Ash, Silica Fume, Slag and Natural Pozzolans in Concrete, Las Vegas, NV: 29-50._http://www.cbu.uwm.edu_(June 30, 2004).

5. FHWA, Recycled Concrete Aggregate, Federal Highway Administration National Review, Federal Highway Administration, Washington, D.C., USA, 2008.

6. Ganjian E, Claisse P, Tyrer M and Atkinson A, 2004a. Preliminary investigations into the use of secondary waste minerals as a novel cementitious landfill liner, Construction \& Building Materials Journal, Vol 18; Number 9; pp. 689-699 ISSN 0950-0618.

7. Malhotra, V.M. 2004. "Role of Supplementary Cementing Materials and Superplasticizers in Reducing Greenhouse Gas Emissions.” Proc., ICFRC International Conference on Fiber Composites, High-Performance Concrete, and Smart Materials, Chennai, India: 489-499.

8. McKay, D.T. 2004. "Sustainability in the Corps of Engineers." a paper presented at the Technical Session 9. Mehta, P.K. 2002. "Greening of the Concrete Industry for Sustainable Development." ACI Concrete International 24(7): 23-28.

10. Naik, T.R., Kraus, R.N., Ramme, B.W., Siddique, R. 2003."Long-Term Performance of High-Volume Fly Ash

11. National Building Museum 2004. "Liquid Stone: New Architecture in Concrete."

12. Swedish National Testing and Research Institute 2003. "Concrete for the Environment." Published on Behalf of the Nordic Network Concrete for Environment, Boras, Sweden, 8 pages.edu/_(2007).

13. Washington, D.C.Ricoh Company, Ltd. 2004. "Sustainable Developments: Planning for our Future." Time Magazine.

14. Worrell, E., \& Galtisky, C. 2004. "Energy Efficiency Improvement and Cost Saving Opportunities for Cement Making." Lawrence Berkeley National Laboratory, Publication No. LBNL-54036, 62 pages.

15. Wu, Z. 2000. "Development of High-Performance Blended Cement." Ph. D. thesis, T. R. Naik advisor, Department of Civil Engineering and Mechanics, College of Engineering and Applied Science, 177 pages. 